\title{
FLOUR FUNCTIONALITY, CHEMICAL AND SENSORY PROPERTIES OF COOKIES FROM TRIFOLIATE YAM FLOUR-SOYBEAN BLENDS
}

\author{
${ }^{*}$ Olawuyi, Y. O. and Oyetola, F. \\ Department of Food Science and Technology, Bowen University, Iwo, Osun \\ State, Nigeria \\ *Corresponding Author: yetundeoluolawuyi@gmail.com
}

\begin{abstract}
Trifoliate yam was used to produce flour which was enriched with soybean flour at varying substitution levels and used to produce cookies. The cookies were analysed for their proximate content, nutritional content and sensory evaluation were carried out on them. The flour was analyzed for its physicochemical, properties. The results showed that enriching trifoliate yam flour with soybean flour increased the protein content. There was also an increase in the fat content with increase in the substitution level. The sensory evaluation showed that the cookie made at $20 \%$ substitution level had the highest overall acceptability score. Enrichment of trifoliate yam flour with soy flour at levels of $10 \%$ to $30 \%$ resulted in a notable increase in the protein content, which is nutritionally advantageous where many cannot afford foods that are rich in protein because of its cost.
\end{abstract}

Keywords: Trifoliate yam; flour; soybean; cookies 


\section{INTRODUCTION}

The use of composite or alternative flours for bread, pastry and pasta in Nigeria has been necessitated by the hike in price of wheat flour and its resultant effect on the economy of the country. Trifoliate yam (Dioscorea dumeturom) is an underutilized yam specie which has been explored for processing into flour in order to increase its consumption. This highly nutritious yam specie has been limited in use due to the hardening it experiences after harvest. The nutritional composition of the baked products (cookies) needs to be well considered especially when the target market are children because of the high rate of malnutrition recorded among children in a country like Nigeria. Cookies are one of the most popular bakery products, widely consumed due to its ready-to-eat nature, good nutritional quality, low cost and longer shelf life that has also been enriched with dietary fibre (Adeleke, and Odedeji. 2010).

Trifoliate yam is an underutilized specie of yam (Alozie et al., 2009). It is not commonly consumed because of its bitter taste, inability to keep for longer time after harvesting and poor capacity of its flour (Akinoso et al., 2016) The high market price of yams is as a result of over dependence on the common yam varieties for food and industrial use, and this incidentally limits industrial exploitation (Adelekan et al., 2013). Due to the low protein content of flours other than wheat, efforts have been made to enrich composite flours with protein-rich legumes such as soybean. Soybean has been recognized to be an ideal grain for meeting protein and energy requirement of both man and animal (Malomo et al. 2012). Soybean can be processed to a variety of products such as soy flour, soy milk, soy yoghurt, soy cake, soy meal, etc. (Balogun et al., 2012)

Snacks are important for toddlers and preschoolers because their stomach is smaller and they need to keep their energy level high. Snack foods are generally preferred by children and teenagers. In these stages of life, the amount and nutritional quality of protein are important because of their essential functions in physical and mental development (Kolawole et al., 2013). The objective of this study was therefore to determine the physical, chemical and sensory properties of cookies prepared from trifoliate yam flour enriched with soybean.

\section{MATERIALS AND METHODS}

Fresh trifoliate yam tubers and soybean were purchased from a local market in Iwo, Osun state. Wheat flour was also purchased to be used as the control sample. The fresh yam tubers were washed, peeled and sliced thinly. The sliced yams were then sun dried and milled into flour. The milled flour was sieved in order to have flour of uniform particle size. The soybeans were sorted to remove 
foreign matters such as stones, leaves, sticks and damaged or infected beans, soaked for $30 \mathrm{~min}$ and boiled for $30 \mathrm{~min}$. The soybeans were dehulled by hand and dried in the sun for 48hours. After drying, the soybeans were milled into flour and sieved to obtain flour of uniform particle size. The soybean flour was then added to the yam flour in different proportions of 10:90, 20:80 and 30:70 and made to pass through a sieve $(2 \mathrm{~mm})$ to obtain uniform particle size of the flour. The cookies were prepared according to the method of Apotiola and Fashakin (2013).

\section{Functional and pasting properties}

The functional (bulk density and oil absorption capacity) and pasting properties of the flour were determined as described by Adelekan et al., (2013).

\section{Proximate analysis}

Moisture, ash, crude fiber and fat (ether extract) contents were determined using the standard AOAC method. Nitrogen content was determined using microkjeldahl and converted to crude protein $(\mathrm{N} \times 6.25)$ while the carbohydrate content was calculated by difference as described by the Association of Official Analytical Chemist (AOAC) (2010). All samples were ground into fine powder and homogenized. All analyses were carried out in triplicates.

\section{Mineral analysis}

The magnesium and iron contents of the cookies were analysed using the Atomic Absorption Spectrophotometer (AOAC, 2005). These two minerals were chosen due to their importance to the target audience of the cookies (children) and because of some constraints in analyzing for more mineral components during the period of analysis.

\section{SENSORY EVALUATION}

Sensory quality characteristics of cookies such as taste, colour, aroma, texture, flavor, crust, crispness as well as overall acceptability were evaluated using voluntary panelists made up of male and female students of Bowen University, Iwo, Osun state. Panelists were trained on testing terminologies and requested to evaluate the cookie samples using a 9-point hedonic scale with the following rating: 9 = Like extremely, 8 - Like very much, 7 - Like moderately, 6 - Like slightly, 5 - Neither like nor dislike, 4 - Dislike slightly, 3 - Dislike moderately, 2 - Dislike very much and 1 - Dislike extremely. 


\section{Statistical analysis}

The means of the data obtained were subjected to analysis of variance (ANOVA) using the Statistical Package for the Social Sciences (SPSS), Version 21; (SPSS, Inc. New Jersey, USA).

\section{RESULTS AND DISCUSSION}

The sample with $100 \%$ TF had the highest peak viscosity of $1819.50 \mathrm{RVU}$, trough value of $1520.50 \mathrm{RVU}$ and final viscosity $2486.00 \mathrm{RVU}$ while the control (100\% wheat flour) had the highest breakdown value of 423.50RVU. Peak viscosity usually indicates the viscous load of the cooked starch or flour and reflects the ability of the starch to swell freely before their physical breakdown (Singh et al., 2003). However, substitution of soy flour decreased the peak viscosity which ranged from $720.50 \mathrm{RVU}$ to $1819.50 \mathrm{RVU}$. This could be due to the presence of fat that decreased the viscosity. The trough and breakdown values indicate that the samples possess high ability to remain undisrupted when subjected to long periods of constant high temperature and ability to withstand breakdown during cooking. Breakdown is a measure of susceptibility of cooked starch granules to disintegration and has been reported to affect the stability of the flour products (Adelekan et al., 2013).

The final viscosity indicates whether the starch material forms a gel or a paste on cooling. It also indicates the strength of the cooked flour paste on cooling. The sample with $50 \%$ TF and $50 \%$ WF had the highest setback viscosity which was significantly higher than other samples. Otegbayo (2014) noted that "high setback value has been associated with a cohesive paste and has been reported to be significant in domestic products such as pounded yam, which requires high setback, high viscosity and high paste stability. The implication of the high set back is that their starches have greater tendency to retrograde, thus they could be more useful as ingredients in products such as noodles where starch retrogradation is desired.

The sample with $80 \%$ TF and $20 \%$ soyflour had the highest pasting time compared to other flour samples. The peak time is a measure of cooking time (Adebowale et al., 2008). The temperature at which the first detectable viscosity was measured is the pasting temperature; it gives an indication of the gelatinization hence, minimum temperature to cook a sample. High pasting temperature can also indicate that the starch exhibits restriction to swelling (Singh et al, 2003). The water absorption capacity of the composite flour increased as the level of substitution increased. Afoakwa and Sefa-Dedeh, (2001) stated that proteins are mainly responsible for the bulk of water uptake and to a lesser extent 
starch and cellulose at room temperature. The increase in the water absorption capacity of soy enriched trifoliate yam flour samples as soy substitution increased maybe attributed to the hydrophilic nature of protein that is present in soy flour which is increasing with a concomittal decrease in starch content (Otegbayo et al., 2013). The implication of this to the texture of the soy enriched trifoliate yam flour is that the highest level of soy substitution absorbs more water and forms thicker paste compared to other samples.

The bulk density values were found to be between $0.52-0.63 \mathrm{~g} / \mathrm{ml}$. It increased with decreasing level of soy flour substitution with sample $100 \%$ TF being denser than all other samples. The bulk density is generally affected by particle size and density of flour and it is very important in determining the packaging requirement, material handling and application in wet processing in the food industry, indicating a lesser packaging material with increase in soy flour substitution (Adebowale et al., 2008). According to Basman et al., (2003) higher bulk density is desirable for greater ease of dispersability of flours. In contrast, however, low bulk density would be an advantage in the formulation of complimentary foods (Ukpabia and Uchechukwu, 2001).

High swelling capacity has been reported as part of the criteria for a good quality product (Niba et al., 2001). The swelling capacity of the flour samples ranged between 3.32- 4.07 . 
Table 1: Pasting and functional properties of composite flour

\begin{tabular}{|c|c|c|c|c|c|c|c|c|c|c|}
\hline Sample & $\begin{array}{l}\text { Peak } \\
\text { viscosity } \\
\text { (RVU) }\end{array}$ & $\begin{array}{l}\text { Trough } \\
\text { viscosity } \\
\text { (RVU) }\end{array}$ & $\begin{array}{l}\text { Breakdown } \\
(\mathrm{RVU})\end{array}$ & $\begin{array}{l}\text { Final } \\
\text { viscosity } \\
(\mathrm{RVU})\end{array}$ & $\begin{array}{l}\text { Setback } \\
\text { viscosity } \\
\text { (RVU) }\end{array}$ & $\begin{array}{l}\text { Pasting } \\
\text { time } \\
\text { (min) }\end{array}$ & $\begin{array}{l}\text { Pasting } \\
\text { temp } \\
\text { (C) }\end{array}$ & $\begin{array}{l}\mathrm{BD} \\
(\mathrm{g} / \mathrm{ml})\end{array}$ & $\begin{array}{l}\text { WAC } \\
(\%)\end{array}$ & $\begin{array}{l}\text { SWC } \\
(\%)\end{array}$ \\
\hline 111 & $\begin{array}{l}1471.50 \pm 1 \\
15.26^{c}\end{array}$ & $\begin{array}{l}1048.00 \pm 1 \\
75.36^{c}\end{array}$ & $\begin{array}{l}423.50 \pm 60.1 \\
0^{d}\end{array}$ & $\begin{array}{l}2105.00 \pm \\
207.69^{c}\end{array}$ & $\begin{array}{l}1057.00 \pm \\
32.53^{\mathrm{b}}\end{array}$ & $\begin{array}{l}5.97 \pm 0 . \\
14\end{array}$ & $\begin{array}{l}87.55 \pm \\
0.49^{\mathrm{ab}}\end{array}$ & $\begin{array}{l}0.59 \pm 0 . \\
01^{\mathrm{b}}\end{array}$ & $\begin{array}{l}0.91 \pm 0 . \\
30^{\mathrm{a}}\end{array}$ & $\begin{array}{l}4.07 \pm 0 . \\
46^{b}\end{array}$ \\
\hline 116 & $\begin{array}{l}1819.50 \pm 3 \\
6.08^{d}\end{array}$ & $\begin{array}{l}1520.50 \pm 2 \\
.12^{d}\end{array}$ & $\begin{array}{l}299.00 \pm 39.1 \\
8^{c}\end{array}$ & $\begin{array}{l}2486.00 \pm \\
67.8^{d}\end{array}$ & $\begin{array}{l}1015.50 \pm \\
4.94^{\mathrm{a}}\end{array}$ & $\begin{array}{l}5.53 \pm 0 . \\
00^{\mathrm{a}}\end{array}$ & $\begin{array}{l}86.45 \pm \\
0.00^{\mathrm{a}}\end{array}$ & $\begin{array}{l}0.63 \pm 0 . \\
00^{c}\end{array}$ & $\begin{array}{l}1.86 \pm 0 . \\
19^{b}\end{array}$ & $\begin{array}{l}3.23 \pm 0 . \\
17^{a}\end{array}$ \\
\hline 209 & $\begin{array}{l}1424.50 \pm 1 \\
27.49^{c}\end{array}$ & $\begin{array}{l}1005.50 \pm 1 \\
12.43^{c}\end{array}$ & $\begin{array}{l}419.00 \pm 15.5 \\
6^{d}\end{array}$ & $\begin{array}{l}2242.00 \pm \\
149.91^{c}\end{array}$ & $\begin{array}{l}1251.50 \pm \\
58.62^{\mathrm{b}}\end{array}$ & $\begin{array}{l}5.86 \pm 0 . \\
09^{b}\end{array}$ & $\begin{array}{l}88.45 \pm \\
0.64^{b}\end{array}$ & $\begin{array}{l}0,61 \pm 0 . \\
02^{\mathrm{bc}}\end{array}$ & $\begin{array}{l}1.09 \pm 0 . \\
23^{a}\end{array}$ & $\begin{array}{l}3.97 \pm 0 . \\
32^{\mathrm{b}}\end{array}$ \\
\hline 324 & $\begin{array}{l}720.50 \pm 2 \\
83^{a}\end{array}$ & $\begin{array}{l}67.00 \pm 2.8 \\
3^{\mathrm{a}}\end{array}$ & $4.00 \pm 0.00^{a}$ & $\begin{array}{l}193.50 \pm 9 . \\
19^{a}\end{array}$ & $\begin{array}{l}126.50 \pm 8 \\
36^{d}\end{array}$ & $\begin{array}{l}6.80 \pm 0 . \\
00^{\mathrm{d}}\end{array}$ & $\begin{array}{l}91.40 \pm \\
1.13^{c}\end{array}$ & $\begin{array}{l}0.52 \pm 0 . \\
02^{b}\end{array}$ & $\begin{array}{l}2.05 \pm 0 . \\
18^{b}\end{array}$ & $\begin{array}{l}3,43 \pm 0 . \\
38^{a}\end{array}$ \\
\hline 420 & $\begin{array}{l}720.50 \pm 2 \\
83^{\mathrm{a}}\end{array}$ & $\begin{array}{l}67.00 \pm 2.8 \\
3^{\mathrm{a}}\end{array}$ & $4.00 \pm 0.00^{a}$ & $\begin{array}{l}193.50 \pm 9 \\
19^{a}\end{array}$ & $\begin{array}{l}126.50 \pm 8 \\
36^{d}\end{array}$ & $\begin{array}{l}6.80 \pm 0 . \\
00^{d}\end{array}$ & $\begin{array}{l}91.40 \pm \\
1.13^{c}\end{array}$ & $\begin{array}{l}0.59 \pm 0 . \\
00^{\mathrm{b}}\end{array}$ & $\begin{array}{l}1.80 \pm 0 . \\
18^{b}\end{array}$ & $\begin{array}{l}3.32 \pm 0 . \\
25^{\mathrm{a}}\end{array}$ \\
\hline 728 & $\begin{array}{l}1458.50 \pm 9 \\
1.22^{c}\end{array}$ & $\begin{array}{l}1333.50 \pm 5 \\
4.45^{d}\end{array}$ & $\begin{array}{l}123.50 \pm 38.8 \\
9^{\mathrm{b}}\end{array}$ & $\begin{array}{l}2345.50 \pm \\
166.17^{c}\end{array}$ & $\begin{array}{l}1012.00 \pm \\
111.92^{\mathrm{c}}\end{array}$ & $\begin{array}{l}6.26 \pm 0 . \\
08^{c}\end{array}$ & $\begin{array}{l}87.20 \pm \\
0.07^{\mathrm{ab}}\end{array}$ & $\begin{array}{l}0.62 \pm 0 . \\
02^{\mathrm{bc}}\end{array}$ & $\begin{array}{l}1.62 \pm 0 . \\
42^{b}\end{array}$ & $\begin{array}{l}3.04 \pm 0 . \\
06^{a}\end{array}$ \\
\hline
\end{tabular}

Means with the same superscripts in the same row are not significantly different $(p<0.05)$.

Sample $111=100 \%$ Wheat flour (WF)

Sample $116=100 \%$ Trifoliate yam flour (TF)

Sample $209=50 \%$ Trifoliate yam flour and $50 \%$ wheat flour

Sample $324=70 \%$ Trifoliate yam flour enriched with $30 \%$ soybean flour

Sample $420=80 \%$ Trifoliate yam flour and $20 \%$ soybean flour

Sample $728=90 \%$ Trifoliate yam flour enriched with $10 \%$ soybean flour

$\mathrm{BD}=$ Bulk density

WAC $=$ Water absorption capacity

$\mathrm{SWC}=$ Swelling capacity

The moisture content ranged between 7.37-9.63\%(Table 2). The moisture content was found to increase as the soy flour substitution increased. Soy flour derived from ground soybeans has been reported to bring moisture to baked goods (Soy foods Association of North America, 2010).

The ash contents of the cookies also increased as the soy flour substitution increased. The result agrees with results of other research studies (Ndife et al., 2011; Olatidoye and Sobowale, 2011). The increase in ash content could be due to the higher ash content of the soy bean than in the trifoliate yam flour. Soy bean has been reported to contain an appropriate quantity of minerals and fat. The protein and fat contents increased with increasing level of soy substitution indicating nutrient enhancement with soy flour substitution ranging between 6.70 - 
$12.82 \%$ for protein and $0.27-4.91 \%$ for fat. These high protein cookies could be of nutritional importance in most developing countries, Nigeria inclusive where many people can hardly afford food high in protein because of cost. The crude fibre ranged between $0.99-3.08 \%$ which were significantly different from each other at $0.05 \%$ level of significance. The sample with $70 \% \mathrm{TF}$ and $30 \% \mathrm{SF}$ (sample 324) had the highest percentage of fibre compared to other samples. This indicates that soy flour enrichment with trifoliate yam flour improved the crude fibre content. The carbohydrate values were significantly different ranging from 67.56 to $81.87 \%$. As the substitution of soy flour increased, the carbohydrate content decreased as expected. Carbohydrate provides energy and from the result obtained, $100 \%$ wheat flour sample had the highest. These cookies will serve as a good source of energy.

The iron content of the samples in $\mathrm{mg} / 100 \mathrm{~g}$ ranged from 3.7 to 7.58 . The samples were significantly different from each other. Enrichment of trifoliate yam flour with soy flour increased the iron content. Iron is a very essential mineral for blood production. Iron is also an essential trace element for normal functioning of the central nervous system and in the oxidation of carbohydrates, proteins and fats (Ogbe and Affiku, 2011). Iron also has a role in energy metabolism, as it facilitates transfer of electrons in the electron transport chain for the formation of ATP (Moyo et al., 2011). The magnesium content of the samples in $\mathrm{mg} / 100 \mathrm{~g}$ ranged from $21.81-24.73$ with the highest being the sample with $70 \%$ TF. Magnesium is an essential mineral for the enzyme activity it also plays a role in regulating the acidalkaline balance of the body. 
Table 2: Proximate and mineral composition of soy enriched trifoliate yam cookies

\begin{tabular}{llllllllll}
\hline $\begin{array}{l}\text { Sam } \\
\text { ples }\end{array}$ & $\begin{array}{l}\text { Moisture } \\
\text { content } \\
(\%)\end{array}$ & $\begin{array}{l}\text { Ash } \\
\text { content } \\
(\%)\end{array}$ & $\begin{array}{l}\text { Crude } \\
\text { protein } \\
(\%)\end{array}$ & Fat $(\%)$ & $\begin{array}{l}\text { Crude } \\
\text { fibre } \\
(\%)\end{array}$ & $\begin{array}{l}\text { Carboh } \\
\text { ydrate } \\
(\%)\end{array}$ & $\begin{array}{l}\text { Energy } \\
(\text { Kcal/10 } \\
0 \mathrm{~g})\end{array}$ & $\begin{array}{l}\text { Iron } \\
(\mathrm{mg} / 100 \\
\mathrm{g})\end{array}$ & $\begin{array}{l}\text { Magnesi } \\
\text { um } \\
(\mathrm{mg} / 100 \\
\mathrm{g})\end{array}$ \\
\hline 111 & $9.63 \pm 0$. & $1.21 \pm 0$. & $7.27 \pm 0$. & $3.01 \pm$ & $0.99 \pm$ & $81.87 \pm$ & 383.47 & $5.13 \pm 0$. & $22.83 \pm 0$ \\
& $28^{\mathrm{a}}$ & $03^{\mathrm{a}}$ & $02^{\mathrm{b}}$ & $0.13^{\mathrm{b}}$ & $0.21^{\mathrm{a}}$ & $0.34^{\dagger}$ & $\pm 0.42^{\mathrm{d}}$ & $02^{\mathrm{c}}$ & $.03 \mathrm{c}$ \\
116 & $7.37 \pm 0$. & $1.67 \pm 0$. & $6.70 \pm 0$. & $2.27 \pm$ & $1.32 \pm$ & $80.36 \pm$ & 370.95 & $7.58 \pm 0$. & $22.18 \pm 0$ \\
& $34^{\mathrm{b}}$ & $11^{\mathrm{c}}$ & $07^{\mathrm{a}}$ & $0.05^{\mathrm{a}}$ & $0.04^{\mathrm{c}}$ & $0.64^{\mathrm{e}}$ & $\pm 1.14^{\mathrm{c}}$ & $02^{\mathrm{f}}$ & $.02^{\mathrm{b}}$ \\
209 & $9.44 \pm 0$. & $1.43 \pm 0$. & $7.27 \pm 0$. & $2.37 \pm$ & $1.18 \pm$ & $78.31 \pm$ & 363.65 & $3.73 \pm 0$. & $21.81 \pm 0$ \\
& $19^{\mathrm{d}}$ & $08^{\mathrm{b}}$ & $03^{\mathrm{b}}$ & $0.05^{\mathrm{a}}$ & $0.01^{\mathrm{b}}$ & $0.06^{\mathrm{d}}$ & $\pm 0.69^{\mathrm{a}}$ & $02^{\mathrm{a}}$ & $.02^{\mathrm{a}}$ \\
324 & $9.30 \pm 0$. & $2.31 \pm 0$. & $12.82 \pm$ & $4.91 \pm$ & $3.08 \pm$ & $67.56 \pm$ & 365.75 & $6.25 \pm 0$. & $24.73 \pm 0$ \\
& $20^{\mathrm{d}}$ & $14^{\mathrm{d}}$ & $0.13^{\mathrm{e}}$ & $0.04^{\mathrm{e}}$ & $0.40^{\dagger}$ & $0.33^{\mathrm{a}}$ & $\pm 0.85^{\mathrm{b}}$ & $02^{\mathrm{a}}$ & $.03^{\mathrm{e}}$ \\
420 & $9.13 \pm 0$. & $2.30 \pm 0$. & $8.02 \pm 0$. & $3.82 \pm$ & $2.78 \pm$ & $73.95 \pm$ & 362.71 & $6.19 \pm 0$. & $23.99 \pm 0$ \\
& $32^{\mathrm{d}}$ & $09^{\mathrm{d}}$ & $06^{\mathrm{d}}$ & $0.06^{\mathrm{d}}$ & $0.04^{\mathrm{e}}$ & $0.03^{\mathrm{b}}$ & $\pm 0.82^{\mathrm{a}}$ & $01^{\mathrm{d}}$ & $.01^{\mathrm{d}}$ \\
728 & $7.90 \pm 0$. & $2.23 \pm 0$. & $7.55 \pm 0$. & $3.46 \pm$ & $2.56 \pm$ & $76.29 \pm$ & 366.51 & $4.01 \pm 0$. & $22.81 \pm 0$ \\
& $09^{\mathrm{c}}$ & $02^{\mathrm{d}}$ & $09^{\mathrm{c}}$ & $0.02^{\mathrm{c}}$ & $0.08^{\mathrm{d}}$ & $0.16^{\mathrm{c}}$ & $\pm 0.26^{\mathrm{b}}$ & $01^{\mathrm{b}}$ & $.02^{\mathrm{c}}$ \\
\hline
\end{tabular}

Means with the same superscripts in the same row are not significantly different $(p<0.05)$.

Sample $111=100 \%$ Wheat flour (WF)

Sample $116=100 \%$ Trifoliate yam flour (TF)

Sample $209=50 \%$ Trifoliate yam flour and $50 \%$ wheat flour

Sample 324=70\% Trifoliate yam flour enriched with 30\% soybean flour

Sample $420=80 \%$ Trifoliate yam flour and $20 \%$ soybean flour

Sample $728=90 \%$ Trifoliate yam flour enriched with $10 \%$ soybean flour

From the sensory evaluation result, the control (cookies with $100 \%$ wheat) had the highest score of 7.85, 7.75, 7.40, 6.80, 7.30, 7.30, 7.35 and 8.05 for taste, colour, aroma, texture, crust, flavour, crispiness and overall acceptability respectively. The 50 -wheat flour: 50 trifoliate yam flour sample had 5.85 for taste, 6.00 for colour, 6.35 for aroma, 5.80 for texture, 5.75 for crust, 5.80 for flavour, 4.70 for crispness and 5.90 for overall acceptability. Among the soy enriched cookies, the sample $90 \%$ TF with soy flour had the highest score for texture, flavour and crispness while the sample $80 \%$ TF with soyflour had the highest score taste, colour, crust, aroma and overall acceptability. Sensory quality is considered a key factor in food acceptance because consumers look out for food with specific sensory characteristics (Adelekan et al., 2016) 
Table3: Sensory evaluation of soy enriched trifoliate yam cookies

\begin{tabular}{lllllllll}
\hline Samples & Taste & Colour & Aroma & Texture & Crust & Flavour & Crispness & $\begin{array}{l}\text { Overall } \\
\text { acceptability }\end{array}$ \\
& & & & & & & & \\
\hline 111 & $7.85 \pm 0.8$ & $7.75 \pm 1.0$ & $7.40 \pm 1.23$ & $6.80 \pm 1.54$ & $7.30 \pm 1.3$ & $7.30 \pm 1.38$ & $7.35 \pm 1.3$ & $8.05 \pm 0.69^{\mathrm{b}}$ \\
& $1^{\mathrm{b}}$ & $7^{\mathrm{b}}$ & $\mathrm{b}$ & $\mathrm{b}$ & $8^{\mathrm{b}}$ & $\mathrm{b}$ & $9^{\mathrm{b}}$ & \\
116 & $5.00 \pm 1.8$ & $3.24 \pm 1.3$ & $6.35 \pm 1.39$ & $5.30 \pm 1.26$ & $5.45 \pm 1.8$ & $5.50 \pm 1.91$ & $4.95 \pm 2.1$ & $5.80 \pm 1.79^{\mathrm{a}}$ \\
& $6^{\mathrm{a}}$ & $7^{\mathrm{a}}$ & $\mathrm{ab}$ & $\mathrm{a}$ & $5^{\mathrm{a}}$ & $\mathrm{a}$ & $1^{\mathrm{a}}$ & \\
209 & $5.85 \pm 1.7$ & $6.00 \pm 1.7$ & $6.35 \pm 1.49$ & $5.80 \pm 1.70$ & $5.75 \pm 1.1$ & $5.80 \pm 1.85$ & $4.70 \pm 1.6$ & $5.90 \pm 1.48^{\mathrm{a}}$ \\
& $9^{\mathrm{a}}$ & $8^{\mathrm{a}}$ & $\mathrm{ab}$ & $\mathrm{ab}$ & $8^{\mathrm{a}}$ & $\mathrm{ab}$ & $3^{\mathrm{a}}$ & \\
324 & $4.55 \pm 1.9$ & $5.60 \pm 1.4$ & $5.95 \pm 1.39$ & $5.35 \pm 1.53$ & $5.60 \pm 1.5$ & $4.85 \pm 1.66$ & $5.05 \pm 1.7$ & $5.30 \pm 1.49^{\mathrm{a}}$ \\
& $6^{\mathrm{a}}$ & $5^{\mathrm{a}}$ & $\mathrm{a}$ & $\mathrm{a}$ & $3^{\mathrm{a}}$ & $\mathrm{a}$ & $9^{\mathrm{a}}$ & \\
420 & $5.80 \pm 2.0$ & $5.95 \pm 1.8$ & $5.85 \pm 1.59$ & $5.45 \pm 1.59$ & $5.70 \pm 1.4$ & $5.35 \pm 1.63$ & $4.85 \pm 1.4$ & $6.05 \pm 1.39^{\mathrm{a}}$ \\
& $2^{\mathrm{a}}$ & $5^{\mathrm{a}}$ & $\mathrm{a}$ & $\mathrm{a}$ & $2^{\mathrm{a}}$ & $\mathrm{a}$ & $2^{\mathrm{a}}$ & \\
& $5.70 \pm 1.6$ & $5.30 \pm 2.0$ & $6.80 \pm 1.74$ & $5.60 \pm 1.47$ & $5.15 \pm 1.5$ & $5.75 \pm 1.80$ & $5.65 \pm 1.3$ & $6.00 \pm 1.72^{\mathrm{a}}$ \\
& $9^{\mathrm{a}}$ & $3^{\mathrm{a}}$ & $\mathrm{ab}$ & $\mathrm{ab}$ & $7^{\mathrm{a}}$ & $\mathrm{ab}$ & $5^{\mathrm{a}}$ & \\
\hline
\end{tabular}

Means with the same superscripts in the same row are not significantly different $(p<0.05)$.

Sample $111=100 \%$ Wheat flour (WF)

Sample $116=100 \%$ Trifoliate yam flour (TF)

Sample $209=50 \%$ Trifoliate yam flour and $50 \%$ wheat flour

Sample $324=70 \%$ Trifoliate yam flour enriched with $30 \%$ soybean flour

Sample $420=80 \%$ Trifoliate yam flour and $20 \%$ soybean flour

Sample $728=90 \%$ Trifoliate yam flour enriched with $10 \%$ soybean flour

\section{CONCLUSION AND RECOMMENDATION}

In conclusion, this study shows that trifoliate yam flour can be used to make acceptable cookies. Enrichment of trifoliate yam flour with soy flour at levels of $10 \%$ to $30 \%$ resulted in a notable increase in the protein content, which is nutritionally advantageous where many cannot afford foods that are rich in protein because of its cost. The sample with the ratio of 80: 20 (trifoliate yam flour and soy bean flour) had the highest overall acceptability and is therefore recommended. 


\section{REFERENCES}

Adelekan A. O., Arisa N.U., Alamu A. and Ogunseye F. R. (2016). Physicochemical, Nutritional and Sensory Characteristics of Chin-Chin made from Trifoliate Yam (Dioscorea dumentorum) Flour Enriched with Pumpkin Seeds (Telfaria occidentalis) Flour. Applied Tropical Agriculture, 21(2), 44-52.

Adeleke, R.O, and Odedeji, J.O. (2010). Functional Properties of Wheat and Sweet potato flour blend. Pakistan Journal of Nutrition, 9, 535-538.

Adebowale, A.A., Sanni, S.A., and Oladapo, F.O. (2008). Chemical, functional and sensory properties of instant yam breadfruit flour. Nigerian Food Journal, 26 (1), 2-12.

Adelekan, A.O., Arisa, N.U., Alamu, A. and Ogunseye, F.R. (2013). Effect of Enrichment of Trifoliate Yam Flour with Pumpkin Seeds Flour on the Pasting Characteristics and the Acceptability of its Product. Journal of Food Process Technology. 4(12), 1-5.

Afoakwa, E.O., and Sefa-Dedeh, S. (2001). Chemical composition and quality changes occurring in Dioscorea dumetorum pax tubers after harvest. Food Chemistry, 75, 85-91.

Akinoso, R., Olatoye, K.K., and Ogunyele, O.O. (2016). Potentials of Trifoliate Yam (Dioscorea dumetorum) in Noodles Production. Journal of food processing and Technology, 7(8), 1-6.

Alozie, Y., Akpanabiatu, M.I., Eyong, E.U., Umoh, I.B., Alozie, G. (2009) Amino acid composition of Dioscorea dumetorum varieties. Pakistan Journal of Nutrition, 8(2), 103-105.

Apotiola, Z.O and Fashakin J.F. (2013). Evaluation of Cookies from Wheat, Yam, and Soybean Blend. Food Science and Quality Management, 14, 1116.

Association of Analytical Chemists (2010). Official Methods of Analysis. Washington DC, USA

Balogun, M.A., Karim, O.R., Kolawole, F.L. and Solarin, A.O. (2012). Quality Attributes of Tapioca Meal Fortified With Defatted Soy Flour. Agrosearch, 12(1), 61-67 
Basman, A., Koksel, H. and Ng, P.K.W. (2003). Utilization of Transglunase use to increase the level of barley and soy flour incorporation in wheat flour breads. Journal of Food Science, 68(8), 2453-2460.

Kolawole, F.L., Balogun, M. A., Opaleke, D.O. and Amali, H.E. (2013). An evaluation of nutritional and sensory qualities of wheat Moringa cake. Agrosearch, 13(1), 87 - 93.

Malomo, O., Ogunmoyela, O. A. B., Adekoyeni, O. O., Jimoh, O., Oluwajoba, S.O. and Sobanwa, M. O. (2012). Rheological and Functional Properties of Soy-Poundo Yam Flour. International Journal of Food Science and Nutrition Engineering, 2(6), 101-107.

Moyo, B., Patrick, J., Masika, P.J., Hugo, A. and Muchenje, V. (2011). Nutritional characterization of Moringa (Moringa oleifera Lam.) leaves. Africa Journal of Biotechnology, 10(60), 12925-12933.

Ndife, J., Abdulraheem, L.O. and Zakari, U.M. (2011). Evaluation of the nutritional and sensory quality of functional breads produced from whole wheat and soybean flour blends. African Journal of Food Science, 5(8) 466-472.

Niba, L.L., Bokanga, M., Jackson, F.I., and Schlimme, D.S. (2001). Physicochemical properties and starch granular characteristics of flour from various Manihot esculenta (cassava) genotype. Journal Education Science, 67(5), 1701-1705.

Ogbe, A.O. and Affiku, J.P. (2011). Proximate study, mineral and anti-nutrient composition of Moringa oleifera leaves harvested from Lafia, Nigeria: potential benefits in poultry nutrition and health. Journal of Microbiology, Biotechnology and Food Sciences, 1(1), 296-308.

Olatidoye, O.P. and Sobowale, S.S. (2011). Effect of full-fat soy-bean flour on the nutritional,physicochemical properties and acceptability of cassava flour. Electronic Journal of Environmental, Agricultural and Food Chemistry, 10(3), 1994-1999

Otegbayo, B.O., Samuel, F.O., and Alalade, T. (2013). Functional properties of soy-enriched tapioca. African Journal of Biotechnology, 12(22), 35833589.

Otegbayo, B.O. (2014). Effect of storage on the pasting characteristics of yam tubers. Nigerian Food Journal, 32(2) 113-119. 
Singh, N., Singh, J., Kaur, I., Sodhi, N.S. and Gill, S.B. (2003). Morphological, thermal and rheological properties of starches from different botanical sources. Food Chemistry, 81, 219-231.

Ukpabia, U.J., and Uchechukwu, N. (2001). Potentials of Chinese yam (Dioscorea esculenta) in bread. In: Proceedings of the Eight Triennal Symposium of the International Society for Tropical Root Crops, African Branch (ISTRC-AB) 12-16 ${ }^{\text {th }}$ Nov. Ibadan Nigeria. 